\title{
Effects of Glyphosate and Endosulfan on SoIl Microorganisms IN SOYBEAN CROP ${ }^{1}$
}

\author{
Efeitos do Endosulfan e Glyphosate sobre Microrganismos do Solo na Cultura da Soja
}

PEREIRA, J.L. ${ }^{2}$, PICANÇO, M.C. ${ }^{3}$, SILVA, A.A. ${ }^{4}$, SANTOS, E.A. ${ }^{5}$, TOMÉ, H.V.V. ${ }^{6}$ and OLARTE, J.B. ${ }^{7}$

\begin{abstract}
Transgenic soybean, resistant to glyphosate, is the most dominant transgenic crop grown commercially in the world. Research works on herbicide and insecticide mixtures and their effects on microorganisms are rarely reported. This work aimed to study the impact of glyphosate, endosulfan and their mixtures on the microbial soil activity in soybean crop. The experiment was carried out in a complete randomized block design with four treatments and five replications. The treatments were glyphosate $480 \mathrm{SL}[540 \mathrm{~g}$ of active ingredient (a.i.) ha-1], endosulfan $350 \mathrm{EC}$ (525 $\mathrm{g}$ a.i. $\mathrm{ha}^{-1}$ ), the glyphosate $480 \mathrm{SL}$ [540 $\mathrm{g}$ of active ingredient (a.i.) ha-1] mixed with endosulfan 350 EC (525 g a.i. ha $\left.^{-1}\right)$ and the control. Microbial activity was evaluated five days aftertreatment application. Glyphosate application was not an impacting factor for soil $\mathrm{CO}_{2}$ production. Endosulfan application (alone or mixed with glyphosate) suppressed $\mathrm{CO}_{2}$ production by microorganisms in the soil. Microbial biomass and microbial quotient were lower in the treatments using endosulfan alone and in those using endosulfan mixed with glyphosate than in the treatments using glyphosate alone and control.
\end{abstract}

Keywords: Glycine max, insecticide, herbicide, soil microorganisms.

\begin{abstract}
RESUMO - A soja resistente ao glyphosate é a cultura transgênica mais cultivada em todo o mundo. Pesquisas envolvendo o impacto de mistura de herbicidas e inseticidas e seus efeitos sobre microrganismos do solo são raramente reportadas. Este trabalho teve por objetivo avaliar o impacto do herbicida (glyphosate), do inseticida (endosulfan) e da mistura de ambos sobre a atividade microbiana do solo na cultura da soja. O delineamento experimental foi em blocos casualizados, com quatro tratamentos e cinco repetições. Os tratamentos foram o herbicida glyphosate $480 \mathrm{SL}$ [540 g de ingrediente ativo (i.a.) ha-1], endosulfan 350 EC (525 g i.a. ha-1), a mistura de glyphosate 480 SL (540 g de i.a. ha-1) com endosulfan 350 EC (525 g i.a. ha ${ }^{-1}$ ) e a testemunha onde se aplicou água. A atividade microbiana foi avaliada aos cinco dias após a aplicação dos tratamentos. A aplicação de glyphosate não afetou a produção de $\mathrm{CO}_{2}$ pela microbiota do solo. A aplicação de endosulfan (isolado ou em mistura com o glyphosate) reduziu a produção de $\mathrm{CO}_{2}$ pelos microrganismos do solo. A biomassa microbiana e o quociente metabólico foram menores nos tratamentos submetidos à aplicação de endosulfan isolado e em mistura com glyphosate, em comparação àqueles submetidos à aplicaçao de glyphosate isolado e à testemunha.
\end{abstract}

Palavras-chave: Glycine max, inseticida, herbicida, microrganismos do solo.

1 Recebido para publicação em 22.2.2008 e na forma revisada em 14.8.2008.

2 Estudante de Doutorado, Dep.de Fitotecnia, Universidade Federal de Viçosa - DFT/UFV, 36570-000 Viçosa-MG, $<$ jardelmail@yahoo.com.br>; ${ }^{3}$ Professor Adjunto, Dep. de Biologia Animal -DBA/UFV, <picanço@ufv.br>; ${ }^{4}$ Professor Associado - DFT/UFV, <aasilva@ufv.br>; ${ }^{5}$ Estudante de Mestrado, Dep. de Fitotecnia, Universidade Federal de Viçosa - DFT/UFV, 36570000 Viçosa-MG, <edsonapsant@yahoo.com.br>; ${ }^{6}$ Estudante de Iniciação Científica - DBA/UFV, <hudsonufv@yahoo.com.br>; ${ }^{7}$ Estudante de Graduação em Agronomia da Universidade Pública de Navarra, Espanha, <elcovax@hotmail.com>.

Planta Daninha, Viçosa-MG, v. 26, n. 4, p. 825-830, 2008 


\section{INTRODUCTION}

Transgenic soybean, resistant to glyphosate, represents a revolutionary breakthrough in weed control technology. Transgenic soybean is the most dominant among all transgenic crops grown commercially in the world. The use of the glyphosate has been increasing in soy crop due to the cultivation of the soybean tolerant to this herbicide.

Glyphosate is a broad-spectrum herbicide used for the control of weeds in glyphosateresistant crops. Glyphosate inhibits 5enolpyruvyl shikimate 3-phosphate synthase, a key enzyme in the synthesis of aromatic amino acids in plants, fungi, and bacteria (Shaner \& Bridges, 2003). Without these amino acids, the plant cannot make required proteins for various life processes, resulting in the plant death (Ware, 2000). Recent studies have demonstrated that glyphosate application resulted in a substantial decrease in the abundance of soil microorganisms (Santos et al., 2004, Santos et al., 2006; Weaver et al., 2007).

The endosulfan is an important insecticide used in the control of insect pests in perennial (as sugarcane and coffee) and annual crops (as cotton and soybean). The commercial product contains a mixture of two diastereoisomers: á-endosulfan (70\%) and âendosulfan $(30 \%)$. The endosulfan sulfate is the main metabolic derivative from endosulfan and can cause damages to soil microorganisms (Barry \& Davies, 2004).

Pesticide applications in large areas of soybean crops are made with two or more products at the same time in order to reduce the cost and time spent on this activity. In addition, mixtures of insecticides and herbicides, often done, can cause antagonistic, addictive or synergist interactions (Rahman \& James, 1993). However, researches about the herbicides and insecticides mixtures and its effects on the microorganisms are poorly reported.

Recycling microorganisms are an important group of organisms that can be disrupted by pesticides applications. They are related to organic matter cycle and its activity can be assessed measuring the soil microbial respiration which is the most useful tool of disturbance identification for these microorganisms (Kennedy \& Smith, 1995).

Studies of micro, meso, and macrofauna impacted by pesticide applications in the agroecosystems are required to sustainable production minimizing the impacts on nontarget species. In view of such facts, this work aimed to evaluate the impact of the glyphosate, endosulfan and its mixture on soil microbial biomass and its activity.

\section{MATERIAL AND METHODS}

The experiment was carried out at the Experimental Station of the Universidade Federal de Viçosa (UFV), Coimbra, Minas Gerais State, Brazil (20॰51’24 "S and 42॰48'10 "W). The soil type of the experimental area resembles the Paleudult of the American Classification, which is nutrient poor with moderate depth and low water permeability (Resende et al., 1988; Staff, 1999). Since 1998, this field has been cultivated using no-tillage cultivation, in the summer with corn and the winter with beans (De Vita et al., 2007).

The chemical weed burndown and the soil preparation were made four weeks before the soybean planting, realized in $05 / 12 / 06$. In the chemical weed burndown, a mixture of the herbicides glyphosate and 2,4-D (1.44 and $0.33 \mathrm{~kg} \mathrm{ha}^{-1}$, respectively) was applied. The soil analysis data, from soil under experimental procedure, are shown at Table 1 . The variety used was transgenic glyphosate-tolerant CD 219 RR with the gene CP4 EPSPS. The cultivation area was under no tillage system and usual agricultural practices were used during the experiment (Fidelis et al., 2003).

The experiment was carried out in a complete randomized block design with four treatments and five replications. The experimental plot was constituted by an area of $10 \times 10 \mathrm{~m}$ with 20 rows spaced $0.5 \mathrm{~m}$ with six seeds per meter. The treatments were the glyphosate 480 SL [540 g of active ingredient (a.i.) ha ${ }^{-1}$, endosulfan 350 EC (525 g a.i. ha ${ }^{-1}$ ), the mixture of glyphosate 480 SL [540 $\mathrm{g}$ of active ingredient (a.i.) ha $\mathrm{h}^{-1}$ plus endosulfan 350 EC (525 g a.i. ha ${ }^{-1}$ ) and the control. The 
Table 1 - Chemical and textural composition of layer of 0-10 cm depth of clayey soil derived from no-till used in the experiment

\begin{tabular}{|c|c|c|c|c|c|c|c|c|c|c|}
\hline $\mathrm{pH}$ & $\mathrm{P}$ & $\mathrm{K}^{+}$ & $\mathrm{H}+\mathrm{Al}$ & $\overline{\mathrm{Al}^{3+}}$ & $\mathrm{Ca}^{2+}$ & $\mathrm{Mg}^{2+}$ & $\mathrm{CEC}$ & $\overline{\mathrm{V}}$ & $\bar{M}$ & $\overline{\mathrm{OM}}$ \\
\hline $\mathrm{H}_{2} \mathrm{O}$ & \multicolumn{2}{|c|}{---- $\mathrm{mg} \mathrm{dm} \mathrm{dm}^{3}----$} & \multicolumn{5}{|c|}{ - } & \multicolumn{2}{|c|}{------- \% \% -------- } & dag $\mathrm{kg}^{-1}$ \\
\hline 5,0 & 8,3 & 68 & 2,62 & 0,2 & 2,3 & 0,6 & 5,65 & 38 & 7 & 2,62 \\
\hline
\end{tabular}

* Analyses carried out at the Soil Physical and Chemical Analysis laboratories (Soils Department of the UFV). CEC, cation exchange capacity; OM, organic matter; V, base saturation; m, aluminium saturation.

control was sprayed only with water and the weeds were controlled by hand hoe.

The treatments were applied 25 days after soybean emergency when the plants had two trifoliolate leaves completely expanded (stadiums V2-V3). $\mathrm{CO}_{2}$ pressurized knapsack sprayer was used. The sprayer had two nozzle (TT 110.02) spaced $1.0 \mathrm{~m}$, pressure of $200 \mathrm{kPa}$ and spray flow of $100 \mathrm{~L} \mathrm{ha}^{-1}$. During the spraying the sky was clear, soil was moist, the wind speed was lower than $5 \mathrm{~km} \mathrm{~h}^{-1}$, the air temperature was $25.2{ }^{\circ} \mathrm{C}$ and the air relative humidity was $78 \%$. The meteorological data during the experiment are in the Figure 1. Microbial respiration was estimated based on the amount of $\mathrm{CO}_{2}$ evolved from the samples of $100 \mathrm{~g}$ of soil, which were placed in flasks containing $100 \mathrm{~mL}$ of $\mathrm{NaOH}\left(0.25 \mathrm{~mol} \mathrm{~L}^{-1}\right)$ under a continuous air flow system (without $\mathrm{CO}_{2}$ and moisture) at 2, 9, 16, 24 and 30 days after soil incubation (Santos et al., 2006).

After the soil samples were sieved in a two-mesh sieve, air-dried and their water content determined, they were weighed and incubated in Erlenmeyer flasks at a water content of $80 \%$ of field capacity (approximately 0.5 bar or $50 \mathrm{kPa}$ ). This was followed by indirect titration of sodium hydroxide with $\mathrm{HCl}$ $\left(0.25 \mathrm{~mol} \mathrm{~L}^{-1}\right)$ so that the remaining $\mathrm{NaOH}$ that did not react with the evolved $\mathrm{CO}_{2}$ was quantified (Anderson, 1982).

In addition to microbial respiration, the following was determined at 12 and 51 DAA: (a) microbial biomass carbon (MBC) by the method described by Vance et al. (1987), replacing-chloroform (fumigation) by microwave oven (irradiation); (b) microbial quotient (qMIC), through the relation between $\mathrm{MBC}$ and the organic $\mathrm{C}$ multiplied by 100; (c) metabolic quotient $\left(\mathrm{qCO}_{2}\right)$, through the relation between

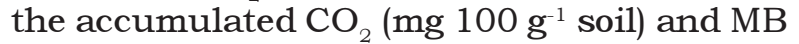
total C (1 $\mathrm{g} \mathrm{g}^{-1}$ soil); and (d) the percentage of bean roots colonised by mycorrhizal fungi was evaluated according to Santos et al., (2006).

The data were submitted to variance analysis by the F-test and the treatment averages for the traits evaluated were compared by the Tukey test at 5\% probability. Regression curves were also fitted for evolution of the accumulated $\mathrm{CO}_{2}$ during the evaluation period.

\section{RESULTS AND DISCUSSION}

The glyphosate application was not an impacting factor for soil $\mathrm{CO}_{2}$ production $(\mathrm{F}=$ $1.31 ; \mathrm{P}=0.2857)$. This result is in agreement with Wardle \& Parkinson, 1990, who also did not observed adverse effect of this product on soil microorganisms probably due the fast glyphosate soil inactivation and degradation (Feng \& Thompson, 1990) (Figure 2).

However, indirect effects of the glyphosate on soil microbial activity may be occurred after long period of cultivation, since the soil microbial activity is influenced by the presence of roots and organic matter in decomposition. Rhizosphere is a region of most intense microbial activity, as a result of the presence of root exudates that represent the largest sources of carbon available for the microorganisms.

Out of the root area influence, the soil can be considered oligotrophic or relatively poor sources of carbon. Microbial activity in these soils is low (Grayston et al., 1997). In this way, repeated applications of glyphosate in transgenic soybean tolerant to glyphosate during the years can cause a reduction in root number and organic matter content, mainly in the interrows, which are free from weeds during the growing season. In these conditions, the proliferation of soil microorganisms is reduced, resulting in poor soil formation and 

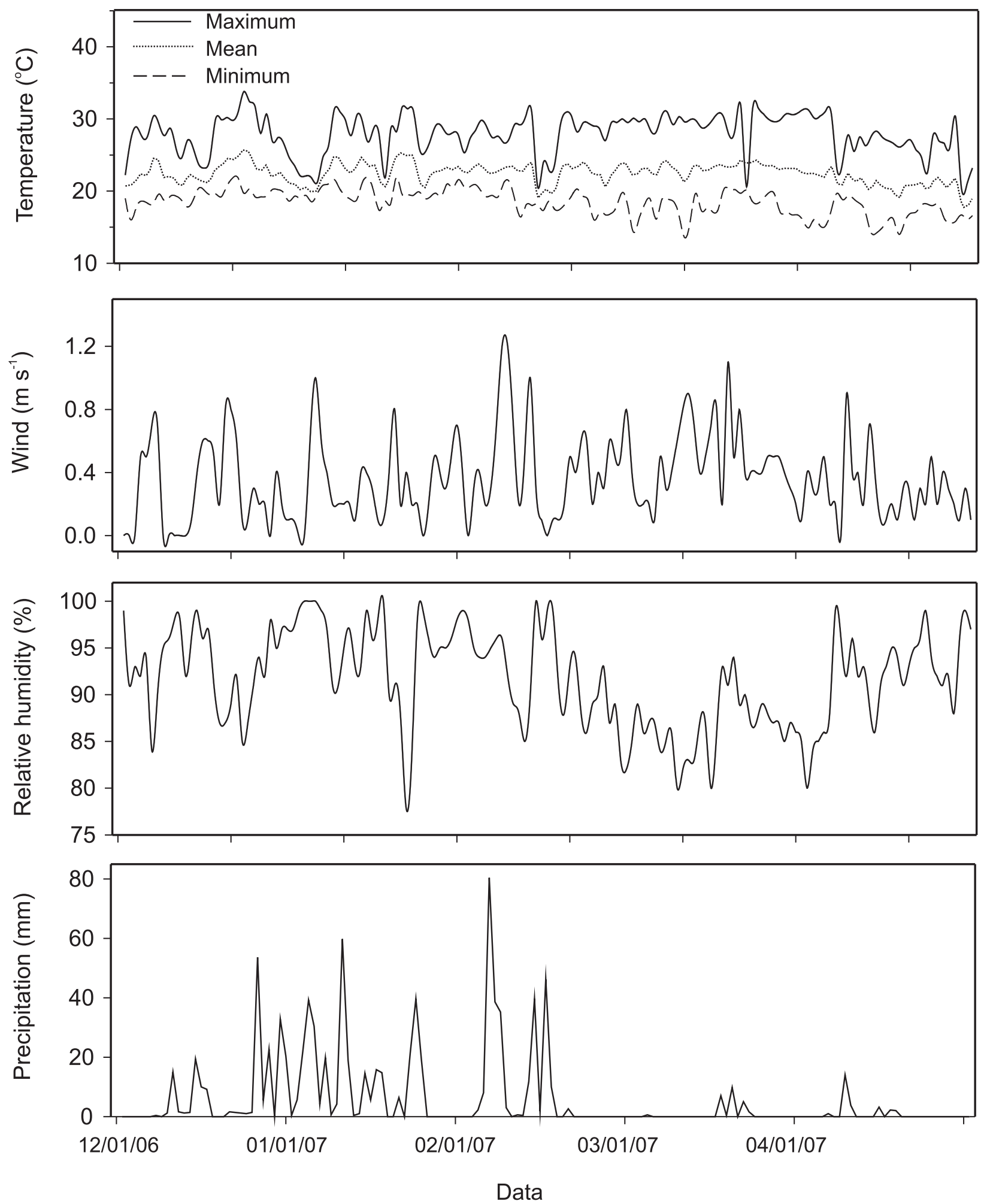

Figure 1 - Climatological data observed during the experiment. 


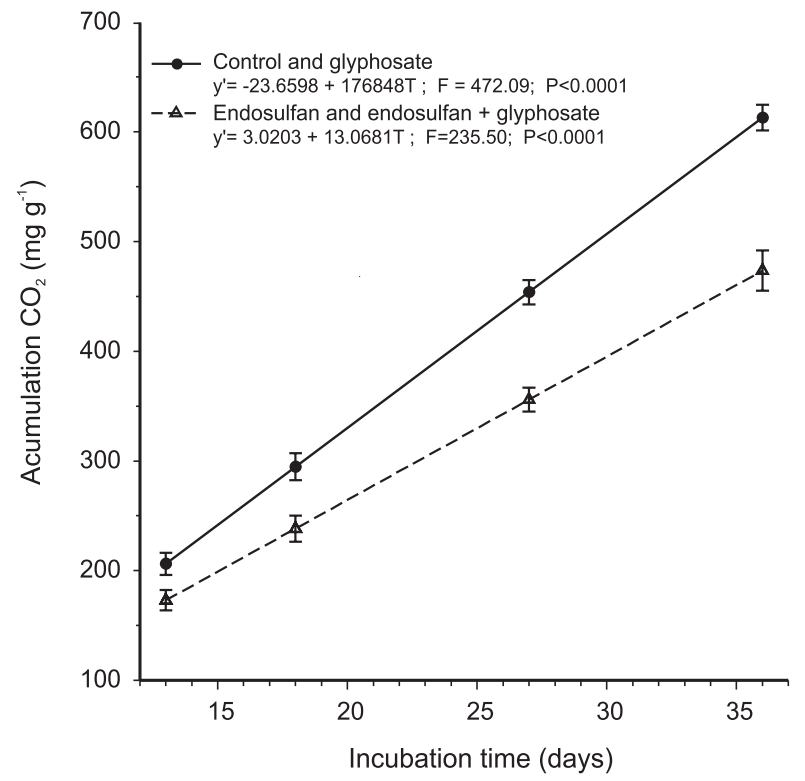

Figure 2 - Accumulated $\mathrm{CO}_{2}$ evolution over 30 days in soil derived from no-till system (NTS) following application of glyphosate $480 \mathrm{SL}$ [ $540 \mathrm{~g}$ of active ingredient (i.a.) ha-1 ${ }^{-1}$, endosulfan $350 \mathrm{EC}\left(525 \mathrm{~g}\right.$ i.a. ha $\left.{ }^{-1}\right)$ and its mixture

nutrient cycling. However, an independent resource study, along the years, will be necessary to confirm these suppositions.

The application of endosulfan alone $(\mathrm{F}=11.28 ; \mathrm{P}=0.0003)$ and in mixture with glyphosate $(\mathrm{F}=19.07 ; \mathrm{P}<0.0001)$ decreased the $\mathrm{CO}_{2}$ production. No statistical differences were observed in the $\mathrm{CO}_{2}$ production between treatment with endosulfan alone or in mixture with glyphosate $(\mathrm{F}=1.16 ; \mathrm{P}=0.3279)$ (Figure 2). Populations of soil microorganisms are very sensitive to the environment's alterations mainly those caused by toxic substances. Endosulfan when applied can reach the soil, forming endosulfan diol and endosulfan sulfate, which has shown high toxicity to soil microbial community (Barry \& Davies, 2004).

Microbial biomass were lower $(\mathrm{F}=17.08 \mathrm{e}$ $\mathrm{p}<0.0001)$ in the treatments submitted to application of endosulfan alone $\left(141.9 \mu \mathrm{g} \mathrm{C} \mathrm{g}^{-1}\right.$ soil) and in the treatments with endosulfan in mixture with glyphosate $\left(207.9 \mu \mathrm{g} \mathrm{C} \mathrm{g}^{-1}\right.$ soil) than in the treatments submitted to application of glyphosate $\left(286.1 \mu \mathrm{g} \mathrm{C} \mathrm{g}^{-1}\right.$ soil) and control (276.3 $\mu \mathrm{g} \mathrm{C} \mathrm{g}^{-1}$ soil). Other studies have demonstrated that the application of insecticide affect the soil microbial biomass. These insecticides may lead to attack induction or inhibition of microorganisms on organic matter. Microbial quotient was bigger in the treatments submitted to application of endosulfan. Jakelaitis et al. (2006) study on the impact of herbicides atrazine and nicosulfuron, did not observe any alteration of soil microbial biomass carbon. According to these authors in soils with high percentage of organic matter, those herbicides were not able to provide substrate for the soil microbiota or they did not cause any toxic effects on it, to the point to alter this indicator of the soil quality.

Microbial quotient were higher $(\mathrm{F}=8.34$ e $p=0.0009$ ) in the treatments submitted to application of endosulfan alone (0.068) and in the treatments with endosulfan in mixture with glyphosate $(0.053)$ than in the treatments submitted to glyphosate application (0.047) and control (0.046). Endosulfan application increases the microbial quotient (qMIC) in relation to the other treatments (Table 2). The relationship between $\mathrm{CO}_{2}$ evolved and the microbial biomass carbon is denominated as microbial quotient (Anderson \& Domsch, 1985). This coefficient indicates that the measure of the microbial biomass turns more efficient in using the resources of the middle, less carbon is lost as $\mathrm{CO}_{2}$ by respiration, being able to this incorporate to the microbial tissue. Soils with high $\mathrm{qCO}_{2}$ are dominated by fastgrowing colonising organisms, reflecting a more unstable environment or further removed from its equilibrium state (Sakamoto \& Oba, 1994; Jakelaitis et al., 2007).

In general, this research has shown that use of endosulfan affected the $\mathrm{CO}_{2}$ production microbial biomass and microbial quotient. However, these factors doesn't affected by glyphosate application.

\section{LITERATURE CITED}

ANDERSON, J. P. E. Soil respiration. In: PAGE, A. L.; MILLER, R. H.; KEENEY, D. R. (Eds.). Methods of soil analysis. Part 1. Madison: American Society of Agronomy, 1982. p. $831-871$ 
ANDERSON, T. H.; DOMSCH, K. H. Determination of ecophysiological maintenance carbon requirements of soilmicroorganisms in a dormant state. Biol. Fert. Soils, v. 1, n. 2 , p. $81-89,1985$

BARRY, M. J.; DAVIES, W. Effects of invertebrate predators and a pesticide on temporary pond microcosms used for aquatic toxicity testing. Environ. Poll., v. 131, n. 1, p. 25-34, 2004.

DE VITA, P. et al. No-tillage and conventional tillage effects on durun wheat yield, grain quality and soil moisture content in southern Italy. Soil Till. Res., v. 92, n. 1, p. 60-78, 2007.

FENG, J. C.; THOMPSON, D. G. Fate of glyphosate in a canadian forest watershed .2. Persistence in foliage and soils. J. Agric. Food. Chem., v. 38, n. 4, p. 1118-1125, 1990

FIDELIS, R. R. et al. Alguns aspectos do plantio direto para a cultura da soja. Biosci. J., v. 19, n. 1, p. 23-31, 2003.

GRAYSTON, S. J.; VAUGHAN, D.; JONES, D

Rhizosphere carbon flow in trees, in comparison with annual plants: The importance of root exudation and its impact on microbial activity and nutrient availability. Appl. Soil Ecol., v. 5 , n. 1, p. $29-56,1997$

JAKELAITIS, A. et al. Atividade microbiana e produção de milho (Zea mays) e de Brachiaria brizantha sob diferentes métodos de controle de plantas daninhas. Planta Daninha, v. 25 , n. 1, p. $71-78,2007$

JAKELAITIS, A. et al. Efeitos de herbicidas no controle de plantas daninhas, crescimento e producão de milho e Brachiaria brizantha em consórcio. Pesq. Agropec. Trop., v. 6, n. 1, p. $53-60,2006$

KENNEDY, A. C.; SMITH, K. L. Soil microbial diversity and the sustainability of agricultural soils. Plant Soil, v. 170, n. 1, p. $75-86,1995$.
RAHMAN, A.; JAMES, T. K. Enhanced activity of nicosulfuron in combination with soil-applied insecticides in corn (Zea mays). Weed Technol., v. 7, n. 4, p. 824-829, 1993.

RESENDE, M.; CURI, N.; SANTANA, D. P. Pedologia e fertilidade de solos: interações e aplicações. Brasília: 1988.

SAKAMOTO, K.; OBA, Y. Effect of fungal to bacterial biomass ratio on the relationship between $\mathrm{CO}_{2}$ evolution and total soil microbial biomass. Biol. Fert. Soils, v. 17, n. 1, p. 39-44, 1994.

SANTOS, J. B. et al. Action of two herbicides on the microbial activity of soil cultivated with common bean (Phaseolus vulgaris) in conventional-till and no-till systems. Weed Res., v. 46, n. 4, p. 284-289, 2006.

SANTOS, J. B. et al. Efeitos de diferentes formulações comerciais de glyphosate sobre estirpes de Bradyrhizobium. Planta Daninha, v. 32, n. 2, p. 293-299, 2004

SHANER, D.; BRIDGES, D. Inhibitors of aromatic amino acid biosyntesis (glyphosate). In: Herbicide action course. West Lafayette: Purdue University, 2003. p. 514-529.

STAFF, S. S. Soil taxonomy. A basic system of soil classification for making and interpreting soil surveys Washington, DC: Natural Resources Conservation Service, 1999.

VANCE, E. D.; BROOKES, P. C.; JENKINSON, D. S. An extraction method for measuring soil microbial biomass-C. Soil Biol. Biochem., v. 19, n. 6, p. 703-707, 1987.

WARDLE, D. A.; PARKINSON, D. Effects of three herbicides on soil microbial biomass and activity. Plant Soil, v. 122, n. 1, p. 21-28, 1990.

WARE, G. The pesticide book. Fresno: 2000. 193 p.

WEAVER, M. A. et al. Effects of glyphosate on soil microbial communities and its mineralization in a Mississippi soil. Pest Manag. Sci., v. 63, n. 4, p. 388-393, 2007. 